\title{
The Nexus between the Establishment of an Enabling Environment and Local Economic Development in the City of Harare
}

\author{
Anesu Mironga \\ College of Business, Peace, Leadership and Governance, Africa University, Mutare, Zimbabwe
}

\begin{abstract}
The ways in which local governments advance and put into operation their policies on the establishment of a conducive environment for businesses to thrive and flourish has great effect and impact on the development of an area. The main actor in Local Economic Development (LED) is local government and it should support the establishment of a conducive and enabling environment that is developmental and facilitates local businesses to grow and succeed. There should be mutual symbiotic relationships between communities, business and local government for Local Economic Development to take place. The study examined the nexus between the establishment of a conducive and enabling environment and local economic development in the City of Harare. Results from this study should assist local authorities in their quest to provide the best for citizens in terms of service delivery and good governance. The study's major goal was to see if the creation of an enabling environment could help people succeed. The study's major goal was to examine the notion that creating an enabling environment leads to local economic development. The study focused on business operators in Machipisa, Mbare Musika and the Central Business District of Harare. The perceptions of these operators and business owners were investigated. A total of 65 business operators were interviewed in the three areas using a structured questionnaire based on Enabling Developmental Environment Scale (EDES). Statistical analysis of data was done through Statistical Package for Social Sciences using descriptive analysis. The results revealed that there is a strong positive correlation (correlation coefficient above 0 ) between an enabling environment and economic growth. This implies that the more the local governments invest in creating an enabling environment the more economic development is achieved.
\end{abstract}

Keywords: Local development, Enabling Environment, Local Economic Development, Service Delivery, Good Governance

\section{INTRODUCTION}

$\mathrm{E}$ conomies at local levels are shaped by processes and policies such as urbanization, migration, national and global trade and production systems. These dynamisms produce risks and opportunities in local areas, necessitating action through the central government's and local governments' implementation of programs and plans aimed at both national and local development.

Strategies for Local Economic Development (LED) are hence planning responses aimed at addressing opportunities and difficulties in ways that benefit local inhabitants. (Masuku, Jili, \& Selepe, 2016, Wekwete, 2014). One of the key roles of local governments is ensuring that a business environment that is conducive to development is established. According to Leigh and Blakely (2013), LED is a calculated and planned intervention approach by local government towards the endorsement of sustainable development within the local economy. Reddy (2016) describes LED as a fundamental response to modern-day trends such as globalisation, accelerated decentralisation and economic adjustments within communities. In all this, the efficient service delivery and the creation of a conducive environment is important.

Through good governance and transparent administration and management, local government, as the level of government closest to the people, can foster this atmosphere (Meyer \& Meyer, 2016). Despite extensive research having studied the dynamics and characteristics of Local Economic Development (Wekwete, 2014; Mandisvika 2015; Simba, Nyandoro, Munyoro, \& Chimhande 2015; Kline \& Moretti 2016; UCLGA, 2016; Musavengane, 2018), less research has examined the role of the establishment of a conducive and enabling environment in Local Economic Development. Past research has focussed mainly on LED, consequently there is an incomplete picture on what is being done by local authorities to promote the thriving and sustainability of local businesses. In light of this, the goal of this study was to determine the relationship between local economic development and the creation of a favorable and enabling environment for enterprises to prosper. The study's major goal was to see if the creation of an enabling environment resulted in Local Economic Development. Specifically the research was driven by three objectives

1. To access Local Economic Development in the City of Harare

2. To explore the perceptions of businesses on the establishment of an enabling environment by the City of Harare.

3. To determine the link between LEDs and the creation of an enabling environment.

To investigate these research questions, a survey was conducted in three areas of the City of Harare where there are high concentrations of businesses; these are Mbare Musika, Machipisa and the Central Business District (CBD). The survey was carried out in April 2021 and a questionnaire which was adapted from the Enabling Developmental 
Environment Scale (EDES) which was developed by Meyer and Keyser (2017) was used. Data collection was done using the SoGoSurvey, an online survey (www.sogosurvey.com). The results show that there is a strong positive correlation (correlation coefficient above 0) between an enabling environment and economic growth. This implies that the more the local governments invest in creating an enabling environment is the more economic development is achieved

Structurally this paper unfolds first with the review of literature, followed by methodology used in conducting the study. The outcomes or findings are then presented and before concluding, recommendations are given.

\section{LITERATURE REVIEW}

The new development trend in local government is enabling environment (CCC, 2012). According to EDA (2018), local governments have the influence on business operators' decisions to invest and create employment. Further to this, local governments have the power and mandate to foster and support more private investment and also to improve the local business environment (EDA, 2018). An enabling environment, according to McKague and Siddiquee (2014) is best defined in the local government context as all of local government- motivated macro-level

The United Nations Industrial Development Organisation (UNIDO, 2008) put forward various factors that are contributory to the establishment of a conducive environment which include an education system that is well functioning, bureaucracy in adequate levels and a road infrastructure that is well maintained (UNIDO, 2008). Meyer (2014) identified twelve influencing factors that have an impact on the creation of a favorable climate for economic development in local communities. These are depicted in Figure 1:

Figure 1: Conceptual Framework

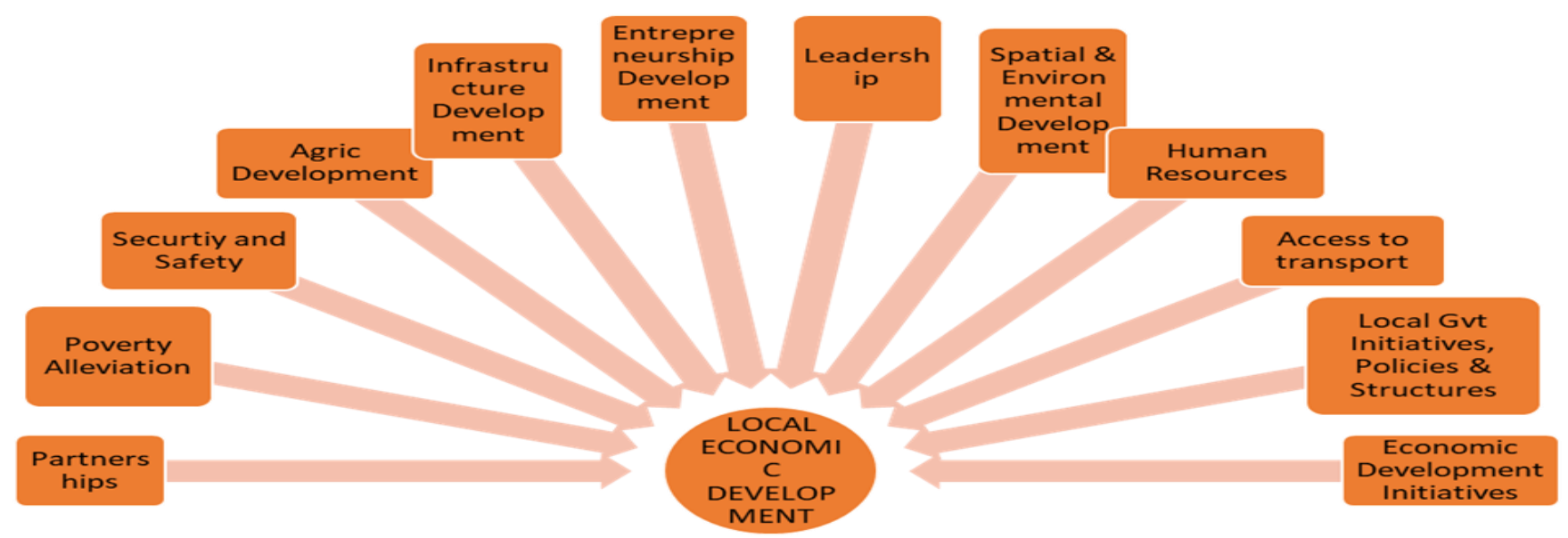

Economic development Initiatives: According to Oduro-Ofori (2011) these are projects, programmes and policies which range from capacity development to infrastructure and these cut across different sectors in the local economy. Local economic development initiatives offer unified and participatory approaches attached to social dialogue and these produce wide-ranging localized responses to aid the informal economy business operators and employees. In order to attain high economic growth there is need to create new businesses (Hofisi, Mbeba, Maredza, \& Choga, 2013).

Formation of partnerships: McQuaid (2013) posits that partnerships encompass cooperation and acting or working together. In public policy it is described as the cooperation in the private or public sector between organisations, institutions and people for mutual benefit (Nkomo, 2017).

Infrastructure Development: Dearth of basic infrastructure is a hindrance to Local Economic Development (Leigh \& Blakely, 2013). Dube (2019) and Gaal and Afrah (2017) view infrastructure as the key catalyst of the alleviation of poverty and it serves as a driver of development. To improve competitiveness and achieve higher economic growth it is critical for local governments to have infrastructure development (Dangra, 2016).

Entrepreneurship Development: Contemporarily, entrepreneurship is fundamental for a region or areas competitiveness, its development and its management of policies (Dallago \& Tortia, 2019). Topxhiu (2012) propels this further by stating that "policy makers and academics agree that entrepreneurship is critical for the development and well-being of a society. Entrepreneurs create jobs. They drive and shape innovation, speeding up structural changes in the economy."

Security and safety: Business and citizens want to feel safe and have protection from injury, danger or risk (Oxford Dictionary, 2021). Local governments and local authority's management are responsible for the delivery of security and safety in their areas and communities (PWC, 2019). At the heart of any locality's prosperity lies security and safety. 
Poverty alleviation and social development initiatives: According to Singh and Chudasama (2020), poverty alleviation and development projects are primarily aimed at reducing poverty among the vulnerable and impoverished in communities using a variety of community-driven and participatory techniques.

Agricultural Development Actions: The thrust towards sustainable agriculture in local governments builds more engaged and active communities thereby leading to a community's economic development (Sharpa, Jackson-Smith, \& Smith, 2011; Gentry, 2013)

Spatial and environmental development: Spatial planning enacts a key role in the provision of a long-term framework for the coordination of policies and development across sectors (Turkoglu, et al., 2012; Stead, 2021). It also assists in the promotion of investment and economic growth while promoting the efficient and optimal use of resources and policies that protect the environment (UN, 2008).

Effective Local Leadership: As Shilangu (2019) posits, the absence of effective leadership in local government has been a major setback for Local Economic Development. Development oriented and effective leadership is required for the success of development projects that are driven locally (Khambule, 2018)

Human Resources Development: There is a strong link between human resources development and Local Economic Development (Saleh, Surya, Ahmad, \& Manda, 2020). King and Osei (2018) concur that good human resources is the bedrock of well managed economies and this is evidenced by good governance, equity, safety nets for the under privileged, the sick and the poor, enough jobs, prosperity and health and education infrastructure that is highly developed.

Access to transport and opportunities: An efficient transport network and transport system provides social and economic opportunities that have positive multiplier effects like additional investments, improved accessibility and increased employment (Rodrigue \& Notteboom, 2020). A good transport infrastructure provides customers and producers access to markets leading to economic growth (Closs \& Bolumole, 2015; Quium, 2019)

Local Government Initiatives, Policies, Capacity and Structures: A local government should provide an appropriate structure for good governance and management of local economic development (UCLG, 2014), which will encourage development integration. Institutional capacity is a prerequisite of good governance and this should incorporate a streamlined and compact institution (WEF, 2011) and political stability is required for the achievement of economic growth and the reduction of poverty (Konig, Da Silva, \& Mhlanga, 2013).

\section{METHODOLOGY}

\section{Research design}

The study was quantitative in nature because it dealt with the quantification and analysis of variables in order to achieve results. The study used the post-positivism paradigm, which is a deterministic philosophy that maintains that causes most likely determine outcomes or effects (Creswell, 2014). In order to respond to the research questions, numerical data was used (Apuke, 2017). Primary data was used in the study.

\section{Sampling Procedure}

According to Sileyew (2019), sampling is the study of a relatively small number of respondents drawn from a larger group in order to establish generalizations about the entire population based on the sample. (Collins, 2011; Denzin\& Lincoln, 2011). The sampling procedure that was used in the study was non-probability sampling, specifically focussing on purposive sampling. In this regard the researcher purposively distributed 65 questionnaires to business operators in Machipisa, Mbare and the Central Business District of Harare. These areas were chosen because of the high concentrations of business operators. In order to observe the COVID-19 protocols, the survey was online, questionnaire links were sent to respondents via email and WhatsApp platform to the targeted business operators. The snowballing sampling techniques was also employed with the assistance of other business operators that had been consulted before.

Data Collection: The questionnaire consisted of 18 questions, 10 of which were measured on a 10-point Likert scale, a scale that is best used for measuring values, knowledge, attitudes, perceptions and behavioral changes (Joshi, Kale, \& Pal, 2015)

\section{Ethical Considerations}

The questionnaire included a cover note which clearly explained the purpose of the research. Issues of anonymity and confidentiality were also explained and also that results will only be reported in the aggregate

\section{RESULTS AND FINDINGS}

Table I: Service Delivery Perception

\begin{tabular}{|c|c|c|c|c|c|}
\hline \multicolumn{2}{|c|}{} & Frequency & Percent & $\begin{array}{c}\text { Valid } \\
\text { Percent }\end{array}$ & $\begin{array}{c}\text { Cumulative } \\
\text { Percent }\end{array}$ \\
\hline \multirow{3}{*}{ Valid } & $\begin{array}{c}\text { Very } \\
\text { poor }\end{array}$ & 19 & 29.2 & 29.2 & 29.2 \\
\cline { 2 - 6 } & Poor & 26 & 40.0 & 40.0 & 69.2 \\
\cline { 2 - 6 } & Average & 20 & 30.8 & 30.8 & 100.0 \\
\cline { 2 - 6 } & Total & 65 & 100.0 & 100.0 & \\
\hline
\end{tabular}

Source: SPSS Primary data

Table 1 above depicts the responses relating to the perception of the respondents regarding the provision of basic services to the three selected municipal areas. Service delivery variables that were considered include water and sewer provision, good quality roads and refuse collection. $29.2 \%$ and $40 \%$ shows a very poor and poor service delivery perception respectively 
bringing it to a total cumulative percentage of $69.2 \%$ representing an unfavorable perception with regards to service delivery. This implies that none of the municipal areas in consideration is doing significant efforts with regards to service delivery. The table does a good job in demonstrating how effective governance, service delivery, and the establishment of an enabling environment propel economic growth. Poor service delivery in this case is resulting in poor business performances in the selected areas hence poor economic development. This is concurring to Shilangu (2019) who argues that the absence of effective leadership and the provision of enabling factors hinders economic development. In a nutshell, it is possible to acknowledge that the creation of an enabling environment and the provision of services leads to economic development in the three municipal areas of Machipisa, Mbare, and the CBD.

Table II: Municipal Area Distribution

\begin{tabular}{|c|c|c|c|c|c|}
\hline \multicolumn{2}{|c|}{} & $\begin{array}{c}\text { Freq } \\
\text { uenc } \\
\text { y }\end{array}$ & $\begin{array}{c}\text { Perce } \\
\text { nt }\end{array}$ & $\begin{array}{c}\text { Valid } \\
\text { Percent }\end{array}$ & $\begin{array}{c}\text { Cumulative } \\
\text { Percent }\end{array}$ \\
\hline \multirow{4}{*}{ Valid } & Machipisa & 20 & 30.8 & 30.8 & 30.8 \\
\cline { 2 - 6 } & Mbare Musika & 17 & 26.2 & 26.2 & 56.9 \\
\cline { 2 - 6 } & CBD & 28 & 43.1 & 43.1 & 100.0 \\
\cline { 2 - 6 } & Total & 65 & 100.0 & 100.0 & \\
\hline
\end{tabular}

Source: SPSS Data

Table II is showing the municipal area distribution by the number of participants per each selected municipal area. This information was further used in explaining table 3 below. Of the 65 total respondents, $30.8 \%$ represents Machipisa, 26.2\% representing Mbare and $43.1 \%$ representing the CBD.

Table III: Descriptive statistics for public service delivery perceptions

\begin{tabular}{|c|c|c|c|c|}
\hline Public services & \multicolumn{3}{|c|}{ Mean Value } & Result \\
\hline $\begin{array}{c}\text { Municipal } \\
\text { Area }\end{array}$ & $\begin{array}{c}\text { Machipisa } \\
\text { N=20 }\end{array}$ & $\begin{array}{c}\text { Mbare } \\
\mathrm{N}=17\end{array}$ & $\begin{array}{c}\mathrm{CBD} \\
\mathrm{N}=28\end{array}$ & $\begin{array}{c}\text { Best } \\
\text { Performing } \\
\text { Municipality }\end{array}$ \\
\hline $\begin{array}{c}\text { Availability of } \\
\text { water }\end{array}$ & 2.34 & 2.0 & 3.42 & $\mathrm{CBD}$ \\
\hline $\begin{array}{c}\text { Planning and } \\
\text { zoning }\end{array}$ & 2.04 & 1.96 & 2.46 & $\mathrm{CBD}$ \\
\hline Quality roads & 1.90 & 1.04 & 3.4 & $\mathrm{CBD}$ \\
\hline $\begin{array}{c}\text { Transport } \\
\text { accessibility }\end{array}$ & 2.22 & 2.12 & 3.56 & $\mathrm{CBD}$ \\
\hline $\begin{array}{c}\text { Refuse } \\
\text { collection }\end{array}$ & 2.4 & 2.3 & 3.48 & $\mathrm{CBD}$ \\
\hline
\end{tabular}

Source: SPSS Data

Table 3 above shows statistics for public service delivery for the 3 municipal areas that were considered. For the purpose of this analysis, variables such as the availability of water, planning \& zoning, quality of roads, transport accessibility and refuse collection were considered. The CBD is having an overall better performance in terms of service delivery as compared to Machipisa and Mbare. However, none of the three municipal areas is above the desirable performance benchmark that promotes economic development. There is need for improvement in all areas regarding service delivery in Machipisa, Mbare and The CBD to achieve economic growth.

Table IV: Perceptions on Creating an Enabling Environment using a 10-point scale

\begin{tabular}{|c|c|c|c|c|c|c|c|c|}
\hline \multirow[t]{2}{*}{ Factor } & \multicolumn{2}{|c|}{ Very Poor (1-2) } & \multicolumn{2}{|c|}{$\begin{array}{l}\text { Poor } \\
(3-4)\end{array}$} & \multicolumn{2}{|c|}{$\begin{array}{c}\text { Average } \\
5-6)\end{array}$} & \multicolumn{2}{|c|}{$\begin{array}{l}\text { Good } \\
(7-10) \\
\end{array}$} \\
\hline & $f$ & $\%$ & $f$ & $\%$ & $f$ & $\%$ & $f$ & $\%$ \\
\hline Safe environment for business & 21 & 32.3 & 34 & 52.3 & 8 & 12.3 & 2 & 3 \\
\hline Strong and quality public participation & 26 & 40 & 28 & 43.1 & 10 & 15.3 & 1 & 1.5 \\
\hline Agricultural development & 27 & 41.5 & 28 & 43 & 9 & 13.8 & 1 & 1.5 \\
\hline Rates and taxes support entrepreneurship & 25 & 38.5 & 36 & 55.4 & 2 & 3 & 2 & 3 \\
\hline Labour regulations support employment creation & 24 & 36.9 & 30 & 26.2 & 9 & 13.9 & 2 & 3.1 \\
\hline Well-developed infrastructure & 35 & 58.8 & 24 & 36.9 & 4 & 6.2 & 2 & 3 \\
\hline Spatial \& environmental development & 31 & 47.7 & 26 & 40 & 5 & 7.7 & 3 & 4.6 \\
\hline Social development \& poverty alleviation & 28 & 43.1 & 26 & 40 & 7 & 10.7 & 4 & 6.1 \\
\hline Stable leadership that articulates polices & 28 & 43.1 & 33 & 50.8 & 3 & 4.6 & 1 & 1.5 \\
\hline $\begin{array}{l}\text { Local governance structures, policies, capacity and } \\
\text { initiatives }\end{array}$ & 29 & 44.6 & 26 & 40 & 9 & 13.8 & 1 & 1.5 \\
\hline
\end{tabular}

$f$ - Frequency of the respondents

$\%$-Percentage of respondents

Source: SPSS Data

Table 4 above is showing a collective perception for the 3 selected municipal areas with regards to creating an enabling environment making use of the factors included in the table.

\section{Perception on Safe environment for business}

The respondents were asked on whether the city council ensures strong and high-quality public participation. As depicted in table 4 above, $32.3 \%$ showed a very poor 
perception, $52.3 \%$ a poor perception and only $3 \%$ showing a good perception. A cumulative percentage of $84.6 \%(32.3+$ 52.3) representing very poor and poor perception respectively makes it clear that close to nothing is being done in relation to the creation of safe environment for business.

\section{Strong and quality public participation}

According to Meyer (2016), public participation is of paramount importance in creating an enabling environment and fostering economic growth. Public participation is a necessary and desired part of community development and should be included in the process of any policy formulation and policy making (Prabakaran, 2011). It encompasses the participation of all stakeholders including business persons, the government, prospective investors and policymakers in establishing a conducive environment for business operators in a bid to achieve economic development. As shown in the table above, a cumulative percentage of $68 \%(40 \%+28 \%)$ for very poor and poor perceptions respectively that is far above the cumulative total for an average and good perception shows that the municipalities for Machipisa, Mbare and the CBD are performing dismally with regards to public participation there by hindering economic development.

\section{Agricultural development}

Nwachukwu (2013) defines agricultural development as "a multi-sectional activity that support and promote positive change in rural and urban areas". As a result, agriculture is regarded as a critical engine of economic growth (FAO, 2020). In the incumbent survey, the respondents were asked on their perceptions on whether there is agricultural development in the City of Harare. A cumulative percentage of $84.3 \%(41.3 \%+43 \%)$ for a very poor perception and a poor perception respectively shows that the city of Harare is not putting much thrust on agricultural development. Only less efforts are being put in place with regards to agricultural development in spite of the fact that Agriculture is one of the highest ranked economic drivers in Zimbabwe. According to Sharpa, Jackson \& Smith (2011); the thrust towards sustainable agriculture in local governments builds more engaged and active communities leading to a community's economic development.

\section{Rates and taxes supporting entrepreneurship}

Taxes and rates levied by the government have a symbiotic relationship with economic development (Oden, 2021). Charging of very high rates and taxes cripples small businesses there by hindering their growth (Awal \& Hassan, 2019). In table 4 above, the majority of respondents have a negative perception on whether the rates and taxes are supporting economic growth. Only a cumulative percentage of $6 \%(3 \%+3 \%)$ shows an average and good perception respectively as compared to the resounding $94 \%$ for a negative perception. This implies that the government must put a thrust in timeously revising its rates and taxes so as to create an enabling environment for business operations hence, economic growth.

\section{Labour regulations support employment creation}

With regards to labour regulations supporting employment creation, a worrisome cumulative percentage of $17 \%$ $(13.9 \%+3.1 \%)$ representing an average and good perception shows that the municipalities of Machipisa, Mbare and Harare CBD are not doing justice in marrying labour regulations and economic development. Much efforts need to be put in place in nurturing labour regulations so that a conducive and enabling environment is created. This can be done through timeously revising the national labour Act and any other relating Acts.

\section{Well-developed infrastructure}

Sifile (2015 asserts that old, dilapidated and poor infrastructure weighs down local governments with repairs. The majority of sewerage systems and road networks in Zimbabwe's largest towns, including as Harare, Mutare, and Gweru, were built in the 1980s and 1990s and are now begging for maintenance from cashstrapped local governments (Dewa, Dziva, \& Mukwashi, 2014). The respondents were asked on their perception with regards to infrastructure development. A plethora of responses indicated that no significant efforts are being put in place by the City of Harare in creating well developed infrastructure. In the table, $58.8 \%$ showed a very poor perception, $36.9 \%$ showed a poor perception bringing it to a total negative perception of $95.7 \%$ that is an unacceptable percentage in as much as economic development is concerned. This in line with the views of Leigh \& Blakely (2013) who argued that death of infrastructure is a hindrance to Local Economic development.

The trend is just the same (that is being negative) for all the remaining indicators which include Spatial \& environmental development, social development \& poverty alleviation, Stable leadership that articulates polices and Local governance structures, policies, capacity and initiatives.

\section{RECOMMENDATIONS AND CONCLUSIONS}

The study's overall goal was to examine business owners' and operators' perspectives on the creation of an enabling environment and local economic development in Harare. Now that all of the responses to the enabling environment have been explored, it is clear that the city of Harare still has a lot of work to do in terms of providing an enabling environment for the elements listed above. The results of the statistics show that quality service delivery and good governance are pivotal in the establishment of an enabling environment, when the business environment is conducive, business growth is evidenced.

There is a strong positive correlation (correlation coefficient above 0 ) between an enabling environment and economic growth. This implies that the more the local 
governments invest in creating an enabling environment is the more economic development is achieved.

The study puts forward the following recommendations:

1. There is need for the City of Harare to have a Local Economic Development Strategic Plan

2. The City of Harare should establish a Spatial Development Framework that will integrate the Department of Housing and the City Planning Department

3. Establishment and strengthening of partnerships between local government, business operators and the local communities should be done

4. There is need for the City to improve employment opportunities and improve the capability for business growth in both informal and formal sectors

5. The Government should have political stability and effective leadership to propel economic development

6. There is need by the City of Harare to prioritize economic development.

The study that was carried out is beneficial to local governments across the world and not just Zimbabwe to make an assessment of their service delivery in relation to the creation of a conducive environment for economic development. Further studies can be conducted making a comparison of various local governments, both urban and rural.

\section{REFERENCES}

[1] Apuke, O. D. (2017). Quantitative Research Methods: A Synopsis approach. Kuwait Chapter of Arabian Journal of Business and Management Review, 6(11), 40-47.

[2] Aronoff, S., (1989). Geographic Information Systems: A Management Perspective. Ottawa: WDL Publications

[3] Awal, M., \& Hassan, S. (2019, October 28). High taxes choking small businesses to the grave. The Standard, p. 1 .

[4] CCC. (2012). Enabling Environment for local development actors. Cambodia: Cooperation Committee for Cambodia

[5] Closs, D. J., \& Bolumole, Y. A. (2015). Transportation's Role in Economic Development and Regional Supply Chain Hubs. $\begin{array}{llll}\text { Transportation } & \text { Journal, } & \text { 54(1), } & \text { 33-54. }\end{array}$ doi:10.5325/transportationj.54.1.0033.

[6] Collins, H. (2011). Creative Research: The Theory and Practice of Research for the Creative Industries. AVA Publications.

[7] Creswell, J. W. (2014). Research design- qualitative, quantitative $\&$ mixed methods approaches (4th Ed). Thousand Oaks: Sage.

[8] Dallago, B., \& Tortia, E. (2019). Entrepreneurship and Local Economic Development: A Comparative Perspective on Entrepreneurs, Universities and Governments. London: Routledge, ISBN 9780367586188.

[9] Dangra, A. (2016, August 2). The Missing Piece in India's Economic Growth Story: Robust Infrastructure. Retrieved from S \& $\mathrm{P}$ Global: https://www.spglobal.com/en/researchinsights/articles/the-missing-piece-in-indias-economic-growthstory-robust-infrastructure

[10] Denzin, N. K., \& Lincoln, Y. S. (2011). The Sage Handbook of Qualitative Research. USA: Sage Publications.

[11] Dewa, D., Dziva, C., \& Mukwashi, K. (2014). Exploring local governance challenges in Zimbabwe under the government of National unity era 2(8). International Journal of Political Science Development, 188-196, https://DOI: 10.14662/IJPSD2014.038.

[12] Dube, C. (2019). Main bottlenecks at the local authority level that could pose challenges for growth and sustainability. Harare: Zimbabwe Economic Policy Analysis and Research Unit.
[13] EDA. (2018, 18 July). How Local Government can create a business enabling environment. Retrieved from Economic Development Australia: https://www.edaustralia.com.au/event/creating-a-moreenabling-local-business-environment/

[14] FAO. (2020). Analyzing food security using household survey data. Retrieved from FAO http://www.fao.org/fileadmin/templates/ess/foodsecurity/Anal yzing_Food_Security_Using_Household_Survey_Data.pdf

[15] Gaal, H. O., \& Afrah, N. A. (2017). Lack of Infrastructure: The Impact on Economic Development as a case of Benadir region and Hir-shabelle, Somalia. Developing Country Studies, 7(1), 49-55.

[16] Gentry, P. M. (2013). Developing Whole Communities: Community Economic Development and Locally Based Sustainable Agriculture. Duke: Duke Law Community Enterprise Clinic.

[17] Hofisi, C., Mbeba, R., Maredza, A., \& Choga. (2013). Scoring local economic development goals in South Africa: why local government is failing to score. 591-595.

[18] Joshi, A., Kale, S., \& Pal, D. K. (2015). Likert Scale: Explored and Explained. British Journal of Applied Science \& Technology, 7(4), 396-403.

[19] Khambule, I. (2018). The role of local economic development agencies in developmental state ambitions. Local economy, 33(3), 287-306.

[20] King, B., \& Osei, E. (2018). Human Resources Development for Economic Development - examples and lessons from ACP countries. Brussels: ACP-EU Economic and Social Unit.

[21] Kline, P., \& Moretti, E. (2016). People, Places, and Public Policy: Some Simple Welfare Economics of Local Economic Development Programs. Annual Review of Economics, 6(1), 629-662.

[22] Konig, G., Da Silva, C. A., \& Mhlanga, N. (2013). Enabling Environments for Agri-business and Agro-industries Development. Rome: Food and Agriculture Organization of the United Nations.

[23] Lechissa, M. (2017). Qualitative Research Methods Training. Bahir Dar: Bahir Dar University.

[24] Leigh, N. G., \& Blakely, E. J. (2013). Planning local economic development: Theory \& economic development: Theory \& practice (5th edition). New-York: SAGE Publications.

[25] Mandisvika, G. (2015). The Role and Importance of Local Economic Development in Urban Development: A Case of Harare. Journal of Advocacy, Research and Education, 2015, 4(3), 198-209.

[26] Masuku, M., Jili, N., \& Selepe, B. (2016). The implementation of Local Economic Development initiatives towards poverty alleviation in Big 5 False Bay Local Municipality. African Journal of Hospitality, Tourism and Leisure, 5(4), 1-11.

[27] McKague, K., \& Siddiquee, M. (2014). Improving the Enabling Environment. In K. McKague, \& M. Siddiquee, Making Markets More Inclusive (pp. 125-132). New York: Palgrave https://doi.org/10.1057/9781137373755_9.

[28] McQuaid, R. (2013). The Theory of Partnerships Why have Partnerships. In S. Osborne, Managing public-private partnerships for public services: an international perspective (pp. 9-35). London: Routledge.

[29] Meyer, D. F. (2014). Local Government's Role in the Creation of an Enabling Developmental Environment. Administration Publica, 22(1), 24-46.

[30] Meyer, D. F., \& Keyser, E. (2017). Formulation and validation of an Enabling Developmental Environment Scale (EDES) for local economic development (LED). Journal of Economics and Behavioral Studies, 9(6), 57-66, ISSN: 22206140.

[31] Meyer, N., \& Meyer, D. F. (2016). The relationship between the creation of an enabling environment and economic 
development: A comparative analysis of management at local government sphere. Polish Journal of Management Studies, 14(2), $150-160$.

[32] Musavengane, R. (2018). Toward Pro-Poor Local Economic Development in Zimbabwe: the role of pro-poor tourism. African Journal of Hospitality, Tourism and Leisure, Volume 7 (1), 1-14.

[33] Nkomo, D. (2017, February 17). Challenges of local governance in Zimbabwe. Retrieved from Zimbabwe Today: http://zimbabwetoday

[34] Oden, C. (2021, April 23). Effect of taxation on the economic development of Edo State. Retrieved from Project Topics: https://www.projecttopics.org/effect-of-taxation-on-the-economicdevelopment.html

[35] Oduro-Ofori, E. (2011). The Role of Local Government in Local Economic Development Promotion at the District (Doctoral Thesis). Dortmund, Germany: Technical University of Dortmund.

[36] Oxford Dictionary. (2021, March 2). Oxford Dictionary. Retrieved from https://www.oed.com/

[37] Prabakaran, M. (2011, March 20). What is Good Governance? Retrieved from Researchgate: https://www.researchgate.net/publication/228123335_What_is_Go od_Governance

[38] PWC. (2019). Achieving safety and security in an age of disruption and distrust. PWC.

[39] Quium, A. S. (2019). Transport Corridors for Wider SocioEconomic. Sustainability, 11, 1-24.

[40] Reddy, P. S. (2016). From National to Local Economic Development (LED): The South African Case. In S. E.D, M. J., \& G. S, Developmental Local Governance. International Political Economy Series. London: Palgrave Macmillan.

[41] Rodrigue, D. J.-P., \& Notteboom, D. T. (2020). Transportation and Economic Development. In D. J.-P. Rodrigue, The Geography of Transport Systems. New York: Routledge.

[42] Saleh, H., Surya, B., Ahmad, D. N., \& Manda, D. (2020). The Role of Natural and Human Resources on Economic Growth and Regional Development: With Discussion of Open Innovation Dynamics. Journal of Open Innovation, 1-24.

[43] Sharpa, J. S., Jackson-Smith, D., \& Smith, L. (2011). Agricultural economic development at the rural-urban interface: Community organization, policy, and agricultural change. Journal of Agriculture, Food Systems, and Community Development, 1(4), 189-204.

[44] Shilangu, L. (2019). Enhancing Local Economic Development Through Effective Leadership and Service Delivery in South African Municipalities. The 4th Annual International Conference on Public Administration and Development Alternatives (pp. 632-
638). 03 - 05 July 2019, Southern Sun Hotel, OR Tambo International Airport, Johannesburg, South Africa: ICPADA.

[45] Sifile, O. (2015). Towards improving service delivery in local authorities. A case of Chegutu Municipality. IOSR Journal of Humanities And Social Science, 20(11), 55-63.

[46] Simba, A., Nyandoro, Z. F., Munyoro, G., \& Chimhande, D. (2015). The local economic development processes in lowincome countries: The case of the metropolis of Chegutu in Zimbabwe. Local Economy: The Journal of Local Policy Unit.

[47] Singh, P. K., \& Chudasama, H. (2020). Evaluating poverty alleviation strategies in a developing country. PLoS ONE 15(1): $\quad$ e0227176. https://doi.org/10.1371/journal.pone.0227176.

[48] Stead, D. (2021). Conceptualizing the Policy Tools of Spatial Planning. Journal of Planning Literature, https://doi.org/10.1177/0885412221992283.

[49] Topxhiu, R. (2012). The role of entrepreneurship and enterprises for local economic development. Academicus International Scientific Journal, 5, 96-107.

[50] Turkoglu, H., Ocakçı, M., Ataöv, A., Uşun, M., Iş̧k, A., \& Güvener, U. (2012). A Participatory Spatial Planning Process: The Case of Bursa, Turkey. 48th ISOCARP Congress 2012. Bursa: ISOCARP.

[51] UCLG. (2014). The Role of Local Governments in Economic Development. United Cities and Local Governments: The Federation of Canadian Municipalities.

[52] UCLGA. (2016). State of Local Economic Development in Zimbabwe. Rabat, Morocco: United Cities and Local Governments of Africa.

[53] UN. (2008). Spatial Planning: Key Instrument for Development and Effective Governance with Special Reference to Countries in Transition. New York and Geneva: United Nations.

[54] UNIDO. (2008). United Nations Industrial Development Organization: Creating an enabling environment for private sector development in sub-Saharan Africa. Vienna: Federal Ministry for Economic Cooperation and Development (FMECD).

[55] WEF. (2011). The Future of Government: Lessons Learned from Around the World. Cologne, Switzerland www.weforum.org: World Economic Forum (WEF).

[56] Wekwete, K. (2014). Local Government and Local Economic Development in Southern Africa. Lilongwe, Malawi: Commonwealth Local Government Forum. 